\title{
Women and COVID-19: reflections for a sexual and reproductive rights-based obstetric care
}

\author{
Mulheres e COVID-19: reflexões para uma atenção obstétrica baseada nos direitos sexuais e reprodutivos
}

Mujeres y COVID-19: reflexiones para una atención obstétrica basada en los derechos sexuales y reproductivos

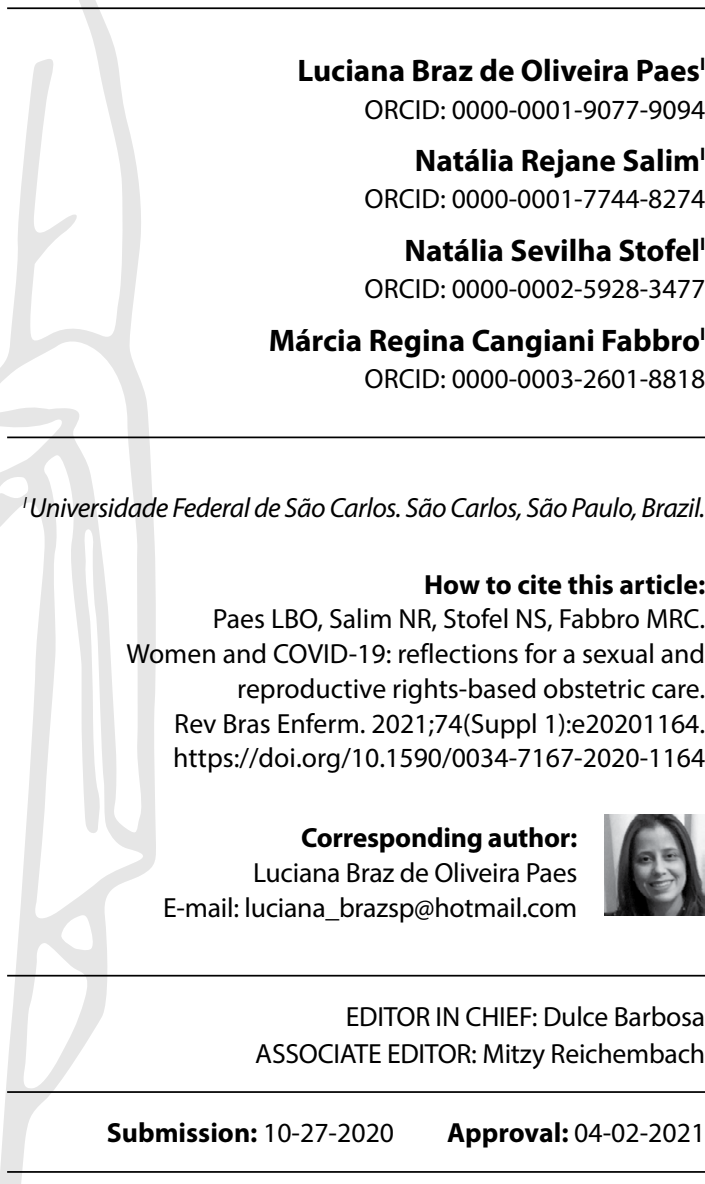

\section{ABSTRACT}

Objective: This essay aims to reflect on the repercussions of the pandemic in obstetric care in the light of sexual and reproductive rights, focusing on delivery and birth care. Results: The reflection shows that the pandemic has accentuated the violation of these rights, which is evidenced by racial inequalities in maternal mortality, as well as restrictions and interventions in childbirth care without scientific evidence, detour of resources, interruption of services, reduced human resources, shortage of medicines and supplies, and imbalances in the provision of health services. Conclusion: It is concluded obstetric care faces even greater barriers in access to health care, just as the pandemic of COVID-19 highlighted inequities, disproportionately impacting vulnerable populations whose human rights are less protected. Descriptors: Women; Coronavirus Infections; Health Care; Obstetrics; Sexual and Reproductive Rights.

\section{RESUMO}

Objetivo: Este ensaio se propõe a refletir sobre as repercussões da pandemia na atenção obstétrica à luz dos direitos sexuais e reprodutivos, com enfoque na atenção ao parto e nascimento. Resultados: A reflexão demonstra que a pandemia acentuou a violação desses direitos, o que se evidencia pelas desigualdades raciais na mortalidade materna, bem como restrições e intervenções na assistência ao parto sem evidência científica, desvio de recursos, interrupção de serviços, recursos humanos reduzidos, escassez de medicamentos e suprimentos e desequilíbrios na prestação de serviços de saúde. Conclusão: Conclui-se que a atenção obstétrica enfrenta barreiras ainda maiores no acesso à saúde, assim como a pandemia da COVID-19 ressaltou as iniquidades, impactando desproporcionalmente populações vulneráveis, cujos direitos humanos são menos protegidos.

Descritores: Mulheres; Infecções por Coronavírus; Atenção à Saúde; Obstetrícia; Direitos Sexuais e Reprodutivos.

\section{RESUMEN}

Objetivo: Esto ensayo propone reflejarse acerca de repercusiones de la pandemia de COVID-19 en atención obstétrica de acuerdo con los derechos sexuales y reproductivos, basado en la atención al parto y nacimiento. Resultados: Reflexión demuestra que la pandemia acentuó la violación de esos derechos, que se evidencia por desigualdades raciales en la mortalidad materna, así como restricciones e intervenciones en asistencia al parto sin evidencia científica, desvío de recursos, interrupción de servicios, recursos humanos reducidos, escasez de medicamentos y suministros y desequilibrios en prestación de servicios de salud. Conclusión: Concluyó que aún la atención obstétrica enfrenta barreras mayores en acceso a la salud, así como la pandemia de COVID-19 resaltó las iniquidades, impactando desproporcionadamente poblaciones vulnerables, cuyos derechos humanos son menos protegidos.

Descriptores: Mujeres; Infecciones por Coronavirus; Atención a la Salud; Obstetricia; Derechos Sexuales y Reproductivos. 


\section{INTRODUCTION}

The pandemic caused by the novel coronavirus disease (COVID-19) was declared a global public health emergency by the World Health Organization (WHO) in December 2019. Women are being disproportionately affected by the consequences of the COVID-19 pandemic - for example, increased gender-based violence as a result of social isolation with their abusive partner. Another reason why there is a greater impact on them is that they are the majority among informal and health care workers. Thus, this health crisis has worsened the inequalities experienced by girls and women and other groups in vulnerable situations ${ }^{(1)}$.

In reproductive health, studies already point to the hypersexualization of women, inequalities regarding the responsibility for child rearing; the detour of resources from routine health services, exacerbating the lack of access to continuity of prenatal care, puerperium, contraception, prevention of sexually transmitted infections, cancer screening; unsafe abortion; among others ${ }^{(1)}$. In addition, situations of obstetric violence are accentuated ${ }^{(2)}$.

There are deep structures of inequality, which makes the pandemic affect people in different ways, so that its effects and impacts are not equal. In the context of sexual and reproductive health care, the pandemic has made conditions of care even more precarious, which under normal circumstances were already precarious in many countries, with increased risk of life. As evidence of this, one can cite an intersectional feminist approach whose results reveal that the pandemic reinforces racial, class and gender inequalities, as well as the confinement perspective makes groups of people more vulnerable to gender violence ${ }^{(3)}$.

In this sense, there is a need to analyze the effects of the pandemic from a gender perspective, which rescues reproductive rights, understood as human rights that guarantee the individual, free and responsible exercise of sexuality, autonomy over one's body and reproductive choice. Furthermore, reproductive rights must guarantee obstetric care and access to quality care that includes the different dimensions of women's lives ${ }^{(2)}$.

Therefore, this essay aims to reflect on obstetric care in the context of the pandemic of COVID-19 and implications for the guarantee of reproductive rights. To do so, it proposes to problematize the repercussions of the pandemic on women's health care in light of sexual and reproductive rights, focusing on delivery and birth care.

\section{Pandemic and mishaps in sexual and reproductive rights}

In the care of women in the gravid-puerperal cycle, the pandemic of COVID-19 directly impacts the violation of human rights. This is because health services around the world, renowned for providing quality maternity care in recent years, are regressing during the pandemic of COVID-19. Some of the restrictions and interventions implemented in childbirth due to this pandemic are not necessary, are not able to limit the contamination of the virus nor have scientific evidence, thus disrespecting human dignity. Therefore, they constitute forms of obstetric violence and result in unnecessary interventions, made without obstetric indication, such as cesarean sections or accelerated and/or instrumental deliveries and the prohibition of the companion in labor ${ }^{(2)}$.
In this sense, with limited understanding of the effects of COVID-19 during pregnancy, physicians are making uninformed decisions not based on scientific evidence. The medical and academic community should recognize the gaps in knowledge, rather than trying to fill them with speculation ${ }^{(4)}$.

When it comes to newborn care, there is evidence that isolating the newborn, early cord clamping, and restricting breastfeeding can lead to long-term detrimental consequences if applied to the general population ${ }^{(4)}$. Moreover, the isolation of the newborn may hinder infection prevention mechanisms, disrupt their physiology, considering that, when separated from their mothers, they present higher heart and respiratory rates and lower glucose levels than those who are placed in skin-to-skin contact. The separation interferes with breastfeeding and can interrupt the innate immune protection and the benefits of breast milk, impact the construction of the bond, in addition to overloading the health system, because the isolation of mother and baby requires double the resources for the care of the binomial ${ }^{(5)}$.

The WHO guidelines for the clinical management of COVID-19 recommend that all pregnant women, including those with confirmed or suspected coronavirus infection, should have access to woman-centered, respectful, skilled care. In this discussion, the route of delivery should be individualized, and a cesarean section should be performed only when clinically justified-there is no evidence to suggest a contraindication to vaginal delivery. Also, it is indicated to practice skin-to-skin contact, breastfeeding, and co-housing with the continuous presence of the newborn regardless of suspicion, probability, or confirmation of COVID-19. Information about precautions - such as hand washing, wearing a mask if you cough, disinfecting rooms and surfaces - should be part of routine care in maternal health services ${ }^{(6)}$.

In Brazil, maternal deaths as a result of COVID-19 are worrisome. The first survey describing the outcomes of the disease in pregnant and postpartum women, conducted in the period from February 26 to June 18,2020 , shows 978 diagnosed and 124 deaths of pregnant or postpartum women, showing a number 3.4 times higher than the total number of COVID-19-related maternal deaths worldwide. This represents a mortality rate of $12.7 \%$ in the Brazilian obstetric population, also higher than the international rates reported so far. This study explains that several factors contribute to high mortality rate in Brazil, such as low quality prenatal care, insufficient resources to manage critical and emergency care, obstetric violence, high rates of caesarean sections. Moreover, another fact is the racial and social disparities in access to maternity services, as evidenced by social determinants, since $71 \%$ of maternal deaths were of black women, and $68 \%$ of deaths were of women living in the North or Northeast Region ${ }^{(7)}$.

The same study highlights barriers to accessing ventilators and intensive care. It also showed that of 978 positive cases in pregnant or postpartum women, 207 (21.2\%) were admitted to the ICU (134 recovered cases and 73 fatal cases), $22.6 \%$ of the women who died were not admitted to the ICU, only $64 \%$ were on invasive ventilation, and no ventilatory support was offered in $14.6 \%$ of all fatal cases, while the remaining $21.4 \%$ received only non-invasive ventilation ${ }^{(7)}$.

Therefore, in addition to the negative repercussions on obstetric care, another study evidenced that there is a disproportionate racial 
impact of COVID-19 between black and white women. The age profile and associated morbidities are equivalent, but black women are hospitalized in worse conditions. While $30 \%$ of white women are hospitalized with low oxygen saturation, $50 \%$ of black women are hospitalized with this parameter, demonstrating less access to care for this group. Furthermore, they are more likely to be admitted to the ICU (19.4\%) with mechanical ventilation $(7.3 \%)$ and to die $(8.9 \%)^{(8)}$.

These data show that limited policies that do not target vulnerable populations and do not include the social determinants of health increase social inequities and sexual and reproductive inequities ${ }^{(9)}$. For example, the current situation of women's human rights in childbirth during this pandemic is a perfect example of how little it takes for health systems to violate the rights of mothers and their babies ${ }^{(2)}$. In addition, pregnant women face specific challenges due to their responsibilities in the workforce, as caregivers for children and other family members, in contact with maternity services, and in clinical settings where the risk of exposure to infection is higher ${ }^{(10)}$.

Globally, women's health studies reinforce an arduous path to securing women's rights during the pandemic of COVID-19. The rigorous implementation of science-driven approaches may not keep pace with the threats of this disease due to reduced human capacity, drug and supply shortages, and increased demand on already overburdened sexual and reproductive health services ${ }^{(9)}$.

Thus, the pandemic of COVID-19 interferes with human rights in many ways, across people, systems, and social levels, whether through the harm caused during pregnancy, the implementation of strict isolation and infection control recommendations, as well as imbalances in health service delivery, disruption of routine essential services, and reallocation of scarce health care workers. The pandemic also showed an increase in interventions without scientific evidence ${ }^{2}$, and detour of resources from essential sexual and reproductive health care by prioritizing the COVID-19 response. Furthermore, the risks of maternal and child morbidity and mortality have increased due to unplanned pregnancies and lack of access to services ${ }^{(10)}$.

Therefore, adversities in reproductive health can only be overcome when public health responses to COVID-19 leverage intersectoral structures based on human rights. That said, there is an urgent need to ensure actions aimed at maternal health in the assistance, during and after the pandemic, which value the access to qualified health care team and services for a model of obstetric care centered on women ${ }^{(9)}$.

\section{FINAL CONSIDERATIONS}

Worldwide, the consequences of COVID-19 are falling hardest on women, both because of the economic and social impacts evidenced in working conditions, especially in the private sphere, and because of the inequities in sexual and reproductive health, which do not recognize the inequalities of gender, race and social class, which, besides being structural, are avoidable, unfair and maintain different forms of violence. In Brazil, the assistance to women in the gravidic-puerperal cycle is weakened, either by lack of planning of specific public policies, or by frequent changes in the management of the Brazilian Ministry of Health, or by the lack of monitoring of the Stork Network. An example is the contraception policy that, when not strongly offered and accompanied in its risks, can aggravate the increase in maternal and neonatal mortality, the increase in unsafe abortions and unwanted pregnancies. Thus, the adequate access to services of care to the gravidic puerperal cycle, the reproductive planning and the complaints that bring threat to the women's health must be considered essential.

Such instability has shamefully placed Brazil in the first place within the ranking of maternal deaths by COVID-19 until August 2020. The recommendations that include pregnant women as a risk group do not enable adequate policies for timely social isolation. Moreover, other proposals are moving through the Brazilian Congress at a pace that does not meet the current need, collaborating so that women remain exposed and vulnerable.

Containment measures that prioritize maternal health are urgent, as well as transparency from the Brazilian Ministry of Health in the disclosure of data for timely intervention. These facts impose an obstacle to the country to achieve the priorities of the global agenda and meet the Sustainable Development Goals by 2030 , especially by the cases of maternal near miss and maternal mortality.

\section{REFERENCES}

1. ONU Mulheres Brasil. Gênero e covid-19 na américa latina e no caribe: dimensões de gênero na resposta [Internet]. Brasília: ONU Mulheres Brasil; 2020[cited 2020 Aug 12]. Available from: http://www.onumulheres.org.br/wp-content/uploads/2020/03/ONU-MULHERES-COVID19_LAC.pdf

2. Sadler M, Leiva G, Olza I. COVID-19 as a risk factor for obstetric violence. Sex Reprod Health Matters [Internet]. 2020 [cited 2020 Sep 2];28(1):1-4. https://doi.org/10.1080/26410397.2020.1785379

3. Hinz K, Zubek I. Why the COVID-19 Pandemic Needs an Intersectional Feminist Approach. Rosa-Luxemburg-Stiftung [Internet]. Berlin: Rosa-Luxemburg-Stiftung; 2020 [cited 2020 Aug 20]. Available from: https://www.rosalux.de/en/news/id/42062/ why-the-covid-19-pandemic-needs-an-intersectionalfeministapproach?cHash=82963ceb141a9a3480bfe2684d6e797b

4. Schmid MB, Fontijn J, Ochsenbein-Kölble N, Berger C, Bassleret D. COVID-19 em mulheres grávidas. Lancet Infect Dis. 2020;20(6):653-3. https://doi.org/10.1016/S1473-3099(20)30175-4

5. Stuebe A. Should infants be separated from mothers with COVID-19? first, do no harm. Breastfeed Med. 2020;15(5):351-2. https://doi. org/10.1089/bfm.2020.29153.ams

6. World Health Organization (WHO). Clinical management of severe acute respiratory infection (SARI) when COVID-19 disease is suspected: interim guidance[Internet]. Genebra: World Health Organization; 2020 [cited 2020 Mar 13]. Available from: https://apps.who.int/iris/ bitstream/handle/10665/331446/WHO-2019-nCoV-clinical-2020.4-eng.pdf?sequence=1\&isAllowed=y 
7. Takemoto MLS, Menezes MO, Andreucci CB, Nakamura-Pereira M, Amorim MM, Katz L, et al. The tragedy of COVID-19 in Brazil: 124 maternal deaths and counting. Int J Gynaecol Obstet. 2020;154-156. https://doi.org/10.1002/ijgo.13300

8. Santos DS, Menezes MO, Andreucci CB, Nakamura-Pereira M, Knobel R, Katz L, et al. Disproportionate impact of coronavirus disease 2019 (COVID-19) among pregnant and postpartum black women in Brazil through structural racism lens. Clin Infect Dis. 2021;72(11):2068-9. https://doi.org/10.1093/cid/ciaa1066

9. Hall KS, Samari G, Garbers S, Casey SE, Diallo DD, Orcutt M, et al. Centring sexual and reproductive health and justice in the global COVID-19 response. Lancet Infect Dis. 2020;395(10231):1175-7. https://doi.org/10.1016/S0140-6736(20)30801-1

10. Hussein J. COVID-19: What implications for sexual and reproductive health and rights globally?. Sex Reprod Health Matters. 2020;28(1):1-3. https://doi.org/10.1080/26410397.2020.1746065 